ఠ

\title{
New developments in the treatment of basal cell carcinoma: update on current and emerging treatment options with a focus on vismodegib
}

This article was published in the following Dove Press journal:

OncoTargets and Therapy

Peter Koelblinger

Roland Lang

Department of Dermatology, Paracelsus Medical University, Salzburg, Austria
Correspondence: Peter Koelblinger Department of Dermatology, Paracelsus Medical University, Muellner Hauptrasse 48, 5020 Salzburg, Austria Tel +435725557842

Email p.koelblinger@salk.at

\begin{abstract}
Basal cell carcinoma (BCC) is the most common form of skin cancer worldwide. Although most BCCs can be treated by relatively simple surgical or nonsurgical methods, some patients with BCC may eventually develop advanced disease which can either be locally destructive or even include metastatic spread. The present review summarizes the current literature on the treatment of both early and advanced BCC with a focus on the hedgehog inhibitor vismodegib which has become an integral part of the management of patients with advanced BCC since its regulatory approval in 2012 .
\end{abstract}

Keywords: basal cell carcinoma, treatment, PTCH1, hedgehog inhibitor

\section{Introduction to the management issues in the treatment of basal cell carcinoma (BCC)}

$\mathrm{BCC}$ of the skin arises from follicular stem cells in the epidermis and is the overall most common cancer in Caucasian people worldwide. ${ }^{1}$ Estimates of annual BCC incidence rates vary widely as BCC diagnoses are typically not reported in national cancer registries. These rates range from $25-172$ new cases annually per 100,000 inhabitants in Europe up to 1,500-1,800 new cases annually per 100,000 inhabitants in the US and Australia. ${ }^{2-4}$ As witnessed for other skin cancers, there has been a gradual increase in BCC incidence over the past decades, which was particularly pronounced in European countries while incidence rates in Australia appear to have stabilized in individuals below the age of 60 years, owing to skin cancer prevention programs. ${ }^{5,6}$

Various environmental, phenotypic and genetic risk factors have been identified to contribute to the development of BCC. Exposure to ultraviolet (UV) radiation particularly intense, intermittent (recreational) exposure - is the most important environmental risk factor for BCC development. ${ }^{4}$ The influence of UV exposure is pronounced in individuals with light skin and a low ability to tan. ${ }^{7,8}$ Higher risk for $\mathrm{BCC}$ development also correlates with increasing age, male gender and immunosuppression. ${ }^{9}$ Mutations in $\mathrm{PTCH} 1$ or $p 53$ represent the most frequent genetic alterations contributing to $\mathrm{BCC}$ development and can be detected in around $70 \%$ and $60 \%$ of BCCs, respectively. ${ }^{10}$ The pivotal inactivating PTCH1 mutations were originally described in families with Gorlin syndrome, a rare, autosomal-dominant inherited disease predisposing to early BCC development. ${ }^{11}$ Loss-of-function mutations in the PTCH1 gene lead to subsequent upregulation of hedgehog signaling and are of particular interest in regard to the present review, as vismodegib (vismo, 
formerly GDC-0449) specifically interacts with this pathway. Vismo binds and inhibits the activating smoothened homologue - which is usually inhibited by a functioning PTCH1 protein - hence inhibiting smoothened-mediated downstream oncogenic hedgehog signaling in BCC. ${ }^{12}$ Physiologically, hedgehog signaling plays a crucial role in cell growth and tissue differentiation during embryogenesis, but is usually downregulated in adult tissues. Besides the frequent loss-of-function mutations in the PTCH1 gene, other mutations leading to oncogenic hedgehog pathway activation and BCC development can affect the smoothened or $S U F U$ genes in decreasing frequency. ${ }^{10}$ Recently, new BCC-associated genes such as PTPN14 and LATS1 as effectors of the Hippo-YAP pathway and $M Y C N$ as well as mutations in the TERT and DPH3-OXNAD1 promoters have been described to be involved in $\mathrm{BCC}$ carcinogenesis. $^{13}$

Despite the complex discoveries regarding the genetic background and the systemic treatment of BCC, management of patients with early BCC is usually straightforward and mostly surgical. Clinically, three different subtypes of BCC can be distinguished: nodular, superficial and morpheaform BCC. The clinical subtype of BCC substantially influences further treatment decisions as it already contains prognostic information. Superficial BCC, which typically presents as an erythematous patch on the trunk of patients, is associated with a low risk of recurrence, whereas nodular or morpheaform BCC may recur more frequently, particularly if additional risk factors for recurrence are present. These include tumor size, location, definition of clinical margins, histological subtype, systemic immunosuppression and previous treatments (in cases of recurrent tumors). ${ }^{14}$ Taking into account these various risk factors, a classification of BCCs into low-, intermediate- and high-risk tumors has been proposed and can facilitate the choice of treatment. ${ }^{15}$ In general, most BCCs can be cured by simple surgical excision. In certain patients, however, surgical treatment may not be feasible, owing to patient- or tumor-related factors. For example, some patients may develop multiple concurrent superficial BCCs and prefer nonsurgical local treatment options, while other patients present with locally advanced and hence unresectable or metastatic BCCs (mBCCs) and qualify for radiotherapy (RT) or systemic treatment with a hedgehog inhibitor such as vismo.

A brief overview of the evidence and efficacy of currently available surgical and nonsurgical treatment options for BCC is given in the next section.

\section{Current and emerging treatment options for BCC \\ Surgical treatment}

Conventional surgical removal with varying safety margins has been the standard treatment of BCC for decades. After excision, histological examination of BCC specimens is most often performed using the vertical section (bread-loaf) technique ${ }^{16}$ This technique has certain limitations, as only about $1 \%$ of tissue margins are actually examined. Hence, tumor recurrence can occur despite a tumor-free margin documented on the histology report. The frequency of tumor recurrence after conventional surgical excision has been analyzed in a large meta-analysis including a total of more than 16,000 BCC specimens. ${ }^{17}$ Recurrence rates for primary BCCs varied between $0.39 \%$ and $3.96 \%$ depending on the size of the surgical margin $(2-5 \mathrm{~mm})$. The authors also found that a positive margin was associated with tumor recurrence in $27 \%$ of cases. Conventional surgical removal of recurrent $\mathrm{BCCs}$, in turn, leads to higher recurrence rates, ranging from $11.6 \%$ to $17.4 \% .{ }^{18-20}$ Hence, Mohs micrographic surgery is recommended for recurrent $\mathrm{BCCs}$ by most international guidelines, ${ }^{14,21}$ at least if other risk factors for recurrence are present. In Mohs surgery, intraoperative evaluation of surgical margins on frozen sections enables the surgeon to perform targeted re-excision of remaining tumor tissue within the same surgical session. For primary BCC, a randomized prospective trial comparing excision by Mohs with conventional excision and histological work-up yielded recurrence rates of $2 \%$ and $4 \%$, respectively. ${ }^{22}$ For recurrent tumors, the same authors reported a rate of $2.4 \%$ vs $12.1 \%$ for Mohs and conventional surgery, respectively. In general, recurrence rates after Mohs surgery range from $1 \%$ to $3 \%$ for primary and from $2 \%$ to $7 \%$ for recurrent BCCs after a follow-up time of 3-5 years. ${ }^{14}$ Hence, if available, Mohs micrographic surgery can be particularly suggested for recurrent tumors or tumors in high-risk locations, for example, the nose or periorificial areas of the head and neck.

\section{Nonsurgical treatment}

For low-risk tumors (ie, superficial BCC), several nonsurgical, either physically ablative or medical, treatments are frequently used in clinical practice. These treatment alternatives are typically considered in patients in whom surgery is contraindicated or impractical due to age or comorbidities and in patients who refuse surgical treatment. If available, also (superficial) RT may be offered in such treatment scenarios. 
Locally ablative treatments include curettage with subsequent electrodessication and cryotherapy. Recurrence rates with these treatments vary greatly, depending on the anatomical site, tumor type and the experience of the treating physician, as no standardized protocols are available. Recurrence may occur within 5 years after treatment of primary $\mathrm{BCC}$ with curettage or cryotherapy in 3\%-19\% and and $8 \%-40 \%$, respectively. ${ }^{20,23-25}$ Both techniques are recommended for low-risk primary BCC after careful patient selection. ${ }^{14,21}$ Due to high recurrence rates, ablative treatment of recurrent $\mathrm{BCC}$ is generally not recommended.

Alternative to ablative therapies and particularly in patients with multiple concurrent low-risk BCCs, topical medical treatments such as 5-fluorouracil (5-FU), imiquimod or photodynamic therapy (PDT) may be considered.

The toll-like receptor agonist imiquimod is the best studied topical treatment and is usually applied five times a week for 6-12 weeks. This regimen is approved for treatment of superficial BCC both in the European Union and the US. Imiquimod is effective in the treatment of superficial $\mathrm{BCC}$ and other types of skin cancer (actinic keratosis, lentigo maligna) through induction of a T-helper-1 cell-dominated antitumor immune response. Clearance rates of superficial BCCs in low-risk locations after topical imiquimod for 6-12 weeks range around $80 \% .{ }^{26-28}$ Low-risk nodular BCCs may also respond to imiquimod in up to $76 \%$ of cases, yet the application in nodular BCC is not routinely recommended. Recurrence of responding lesions is possible and tends to occur early, typically within the first 24 months after treatment.

The topically applied chemotherapeutic agent 5 -FU is widely used as a field treatment of actinic keratosis, but has been studied less extensively in BCC. At least one randomized, controlled trial showed non-inferiority of 5-FU compared to PDT in the treatment of superficial BCC, which justifies the recommendation of its use in this tumor subtype in different guidelines. ${ }^{29}$ The probability of tumor-free survival 5 years after treatment in this trial was $62.7 \%$ for PDT and $70.0 \%$ for 5 -FU (applied twice daily for 4 weeks).

Another, possibly emerging topical treatment option for superficial or low-risk nodular BCC is ingenol mebutate. Similar to imiquimod, this substance induces an antitumor immune response. Currently, ingenol mebutate is approved only for the use in field cancerization with actinic keratosis. Evidence of its efficacy in (superficial) BCC is limited to case reports and series as well as an early randomized Phase II dose-finding trial. ${ }^{30-32}$ Treatment with ingenol mebutate has mostly been evaluated in patients with superficial BCC The $0.05 \%$ concentration appears to be the most efficacious. ${ }^{30}$ Yet, efficacy needs to be further confirmed in larger prospective studies, before ingenol mebutate may eventually be established as another topical treatment option in BCC.

PDT with either 5-aminolevulinic acid (5-ALA) or methyl-aminolevulinate (MAL) utilizes the photosensitizing properties of these substances to induce a photodynamic reaction through enhanced light absorption by protoporphyrin IX. Standardized PDT protocols for 5-ALA and MAL vary slightly in terms of the duration of topical application of the respective photosensitizer (3-6 hours). Treatment is typically repeated after 1 or 2 weeks and occasionally once more at a later time point. The main side effect of PDT is localized pain in the area of treatment, which often mandates different forms of (local) anesthesia. Efficacy of 5-ALA- and MALPDT in the treatment of different forms of BCC appears similar, which has been directly shown in a small comparative study in nodular BCC. ${ }^{33}$ Response rates after PDT range from $87 \%$ to $97 \%$ for superficial $\mathrm{BCC}^{34,35}$ and from $33 \%$ to 91\% in nodular BCC..$^{36,37}$ Tumor thickness appears to be the most important predictor of response to PDT in nodular tumors. Hence, PDT should only be considered in superficial nodular tumors. ${ }^{14}$ Recurrence rates after PDT are roughly comparable to those after cryotherapy (around 20\% after 5 years). ${ }^{34,35}$ The main advantage of PDT is cosmetic outcome which has been repeatedly shown to be superior both to surgery and cryotherapy. PDT is therefore recommended as a treatment of choice for patients with multiple superficial or thin nodular BCCs, particularly if located at cosmetically important locations. Recently, daylight PDT - using the sun as a natural light source - has largely replaced conventional PDT in the treatment of non-hyperkeratotic actinic keratosis or fields of actinic damage on the face and scalp..$^{38}$ Daylight PDT is associated with a significant pain reduction compared to conventional PDT, while being comparably efficacious even after 6 and 12 months of follow-up. ${ }^{39-41}$ An early explorative study of daylight PDT in BCC suggests unchanged efficacy also in this type of nonmelanoma skin cancer. ${ }^{42}$ Yet, larger studies are necessary before daylight PDT may also be recommended as a conservative treatment alternative for BCC.

\section{Radiotherapy}

Different forms of local RT may be considered as an alternative to surgical treatment of BCC. These include superficial $\mathrm{RT}$, conventional RT with electron beams and brachytherapy. 
Due to the inevitably occurring cutaneous long-term sequelae of RT (impaired cosmetic outcome, increased carcinogenesis), primary RT is recommended only in patients above the age of 60 years who are not amenable to or refuse surgery. ${ }^{14,21}$ Using superficial RT (soft X-rays, 20-50 kV, 40-60 Gy), Zagrodnik et al reported an overall 5-year recurrence rate of $15.8 \%$ after primary treatment of $175 \mathrm{BCCs}$. The recurrence rate was lower in patients with nodular $\mathrm{BCC}$ compared to those with superficial or sclerodermiform BCC $(8.2 \%$ vs $26.1 \%$ and $27.7 \%$, respectively). ${ }^{43}$ A more recent retrospective analysis of 712 BCCs (631 of which were nodular) treated primarily with superficial RT showed a 5-year recurrence rate of $4.2 \% .{ }^{44}$ The only prospective trial comparing different forms of RT (predominantly brachytherapy) with surgery in primary BCC of the face measuring less than $4 \mathrm{~cm}$ in 347 patients yielded a 4 -year failure rate of $7.5 \%$ in the RT compared to $0.7 \%$ in the surgery group. ${ }^{45}$ In addition, the short- to mid-term cosmetic outcome after RT was inferior to that of surgery in this trial, which again supports the recommendation of a primarily surgical approach in most patients. Adjuvant RT after primary resection with positive margins, in turn, is a more established RT indication in BCC, particularly in tumors with a perineural growth or invasion of cartilage or bone. RT is also recommended in cases of tumor recurrence in surgically difficult locations either as definitive or as adjuvant treatment. ${ }^{14,21,46}$ Locally advanced $\mathrm{BCC}(\mathrm{laBCC})$ or $\mathrm{mBCC}$, which is discussed in further detail in this review, usually requires a multidisciplinary therapeutic approach. Local RT is a fundamental component of this complex treatment strategy and can be initiated either primarily or as an adjuvant therapy.

\section{Systemic treatment in advanced BCC}

Advanced BCC is defined as either locally advanced and unresectable or metastatic disease. As outlined above, most "typical" BCCs can be managed with a relatively low risk of recurrence by surgical and nonsurgical methods. At some point, however, particularly after repeated recurrences with involvement of underlying structures such as bones, cartilages or muscles, a BCC may be deemed unresectable by the treating physicians. The incidence of unresectable laBCC can hardly be estimated, as the definition of unresectable disease largely depends on the existing expertise at the respective dermatooncological center and is also a matter of perspective. In some tumors, for example, surgery may be technically possible, but would be associated with functional impairments and marked morbidity despite a high remaining risk of recurrence. The incidence of $\mathrm{mBCC}$ has been estimated at $0.0028 \%-0.55 \%$ in patients previously diagnosed with $\mathrm{BCC} .{ }^{47}$

Historically, laBCC or mBCC was treated by chemotherapy after exhaustion of surgical and radiotherapeutic treatment options. Cisplatin-based monotherapy or combination regimens is most frequently used. Despite reports of partial or complete responses to different regimens, the therapeutic benefit of chemotherapy has never been demonstrated in prospective randomized trials. ${ }^{48,49}$ Hence, chemotherapy is currently not recommended for the treatment of advanced BCC by international guidelines. ${ }^{14,21}$

The importance of hedgehog pathway inhibitors such as vismo or sonidegib in the treatment of advanced BCC has already been mentioned in the introductory section of this review. Five years after the initial report of clinical data on vismo, ${ }^{12}$ the first Phase I study reporting on the second FDA - and European Medicines Agency (EMA) - approved smoothened inhibitor, sonidegib, was published..$^{50}$ Most lately, 42-month follow-up results of the Phase II BOLT trial of sonidegib in advanced BCC were presented at the 2018 American Society of Clinical Oncology Annual Meeting. ${ }^{51}$ This trial, first reported on in $2015,{ }^{52}$ compared two dosing regimens (200 vs $800 \mathrm{mg}$ per day) of sonidegib in a double-blinded, 1:2 randomized fashion. After 42 months, the overall response rate (ORR) by central review in this trial remained stable at $56.1 \%$ and $46.1 \%$ for the 200 and the 800 $\mathrm{mg}$ dose in laBCC, respectively. In $\mathrm{mBCC}$, the ORR was $7.7 \%$ and $17.4 \%$, respectively. The disease control rate was approximately $90 \%$ in both groups, irrespective of the dosing regimen. ${ }^{51}$ Efficacy and side effect profile of sonidegib trial appear generally comparable to results from large-scale studies with vismo, ${ }^{53-55}$ although direct comparative clinical studies would be necessary to thoroughly assess potential differences. For a detailed review on the pharmacology and clinical utility of sonidegib in advanced BCC, we refer to a recent article by Wahid et al in this journal. ${ }^{56}$

It has been found that BCCs harbor the highest mutational burden of all human cancers. ${ }^{57}$ As mutational burden is a known predictor of response to cancer immunotherapy, for example, with PD-1 inhibitors, one can speculate that patients with advanced BCC are likely to respond to anti-PD-1 antibody-based immunotherapy. Several case reports and series reporting remissions of laBCC or $\mathrm{mBCC}$ after anti-PD1 therapy support this hypothesis. ${ }^{58-63}$ Several prospective controlled trials (ClinicalTrials.gov identifiers NCT03132636, NCT03521830 and NCT02690948) have been designed to further explore the potential of PD-1 antibodies as an emerging treatment option in advanced BCC. 


\section{Pharmacology, efficacy, safety and tolerability of vismo}

In 2009, von Hoff et al were the first to report the clinical activity of vismo in a Phase I trial including 33 patients with advanced BCC (15 with laBCC, 18 with $\mathrm{mBCC}) .{ }^{12}$ Vismo was administered orally at three different dose levels (150, 270 or $540 \mathrm{mg}$ once daily [QD]). Sixteen partial and two complete responses were assessed by cross-sectional imaging or physical examination. Progressive disease occurred in four patients, while the remaining 11 patients had stable disease. No dose-limiting toxicities were reported despite continuous drug administration for up to 19 months.

An update of this Phase I trial with vismo was published by Lorusso et al in $2011 .{ }^{64}$ One additional partial response was reported in the original study population, resulting in an ORR of $58 \%$ with a median duration of response (DOR) of 12.8 months (range: 3.7-26.4 months). Pharmacokinetic(s) (PK) analyses led to a recommended Phase II dose of $150 \mathrm{mg}$ QD, since administration of higher vismo doses did not increase steady-state plasma concentrations.

A separately published detailed PK analysis of this trial revealed a central role of plasma protein binding, particularly to alpha-1-acid glycoprotein, which explains the unusual, nonlinear PK of vismo. ${ }^{65}$ Further studies analyzing the PK after single and multiple dosing of oral and intravenous vismo in healthy subjects showed that solubility-limited absorption is the second mechanism contributing to the nonlinear PK of vismo ${ }^{66}$ Based on these peculiar PK results, Lorusso et al also investigated two alternative dosing schedules of vismo (150 mg three times per week or once weekly, both after an initial 11-day QD loading phase) compared to the recommended Phase II dose of $150 \mathrm{mg}$ QD.${ }^{67}$ However, mean total and unbound steady-state concentrations of vismo were lower after both alternative dosing schedules. Hence, the $150 \mathrm{mg}$ QD dose was carried forward in subsequent studies. An additional pharmacological study by Sharma et al evaluated the effect of food intake or fasting on the PK of vismo. ${ }^{68}$ Although a high-fat meal was found to increase the plasma exposure to a single dose of vismo, at steady state, no influence of dietary intake on exposure to vismo was detected. Therefore, oral intake of vismo can be recommended with or without food.

The first results of the pivotal Phase II ERIVANCE study were published by Sekulic et al and led to approval of vismo for the treatment of advanced BCC both by the FDA and the EMA in 2012 and 2013, respectively (Table 1). ${ }^{69}$ A 12-month update and a final report of this study were subsequently published. ${ }^{53,70}$ ERIVANCE was a single-arm, two-cohort, international multicenter study with the primary end point of ORR assessed by central review. The study population comprised a total of 104 patients, 71 with laBCC and 33 with $\mathrm{mBCC}$. In the initial analysis 9 months after accrual of the last patient, independent review yielded an ORR of $30 \%$ and $43 \%$ for $\mathrm{mBCC}$ and laBCC, respectively. ${ }^{69}$ Response rates assessed by local investigators were generally higher throughout the study, reported at $48.5 \%$ and $60.3 \%$ in the final analysis for $\mathrm{mBCC}$ and laBCC, respectively. ${ }^{53}$ Disease control could be achieved in the majority of patients, while progressive disease was rare at the initial assessment of response (two patients with $\mathrm{mBCC}$ and six patients with laBCC). Regarding secondary end points, median DOR was 14.8 and 26.2 months and median progression-free survival was 9.3 and 12.9 months, again referring to $\mathrm{mBCC}$ and $\mathrm{laBCC}$ in the final analysis of the trial, respectively. Median overall survival was only reached in the $\mathrm{mBCC}$ cohort at 33.4 months. A total of 33 deaths $(31.7 \%)$ was reported, $17(16.3 \%)$ of which were the result of progressive disease. Median duration of vismo treatment was comparable in both cohorts (mBCC: 12.9 months, laBCC: 12.7 months). The median time to overall response appeared to be shorter in the mBCC (57 days) than in the laBCC cohort (140 days). The ERIVANCE trial was also the first to report on typical hedgehog inhibitor-related adverse events (AEs). These include muscle spasms, alopecia, dysgeusia and weight loss in decreasing frequency among others. At least one AE was reported in $100 \%$ of patients. The incidence of treatmentrelated AEs increased with the duration of exposure to vismo in this trial, as demonstrated by comparison of patients treated for less and more than 12 months. Overall, $92 \%$ of patients had discontinued treatment by the time of the final analysis. Disease progression was the most common reason for treatment discontinuation in patients with metastatic disease (51.5\%), while patients with laBCC most often discontinued treatment based on their own decision $(32.4 \%)$ or because of AEs ( $24 \%$ of patients).

After regulatory approval of vismo, Chang et al reported on 119 patients with advanced $\mathrm{BCC}$ who received vismo in an expanded access study (Table 1). ${ }^{71}$ Sixty-two and 57 of these patients had laBCC and $\mathrm{mBCC}$, respectively. In addition, 19 patients with basal cell nevus syndrome were included in this study. Efficacy was evaluable in 95 patients and was comparable to the ERIVANCE study: an ORR of $46.4 \%$ and $30.8 \%$ was reported in laBCC and $\mathrm{mBCC}$ patients, respectively. Disease control was achieved in $94.6 \%$ (laBCC) and $82.1 \%$ (mBCC) of patients. Progressive disease was only 
Table I Summary of efficacy and safety findings of the largest clinical trials investigating vismodegib in BCC

\begin{tabular}{|c|c|c|c|}
\hline Study & Study design & Efficacy findings & Safety findings \\
\hline ERIVANCE ${ }^{66,67,50}$ & $\begin{array}{l}\text { Phase II, two-cohort, multicenter study: } \\
\text { Advanced BCC }{ }^{a} \\
\text { Vismodegib I50 mg QD n=104 } \\
\text { (7I laBCC and } 33 \mathrm{mBCC} \text { patients) }\end{array}$ & $\begin{array}{l}\text { - ORR (local review): 60.3\% (laBCC) } \\
\text { and } 48.5 \% \text { (mBCC) } \\
\text { - PFS: } 12.9 \text { (laBCC) and } 9.3 \text { months } \\
\text { (mBCC) } \\
\text { - DOR: } 26.2 \text { (laBCC) and I } 4.8 \text { months } \\
\text { (mBCC) }\end{array}$ & $\begin{array}{l}\text { Frequent any-grade AEs: muscle spasms } \\
\text { (7I\%), alopecia }(66 \%) \text {, dysgeusia }(55 \%) \text {, } \\
\text { weight loss }(51 \%) \text {, fatigue ( } 43 \%), \text { nausea } \\
\text { ( } 33 \%) \text {, diarrhea }(27 \%) \\
\text { Reason for treatment discontinuation: } \\
\text { PD }(28 \%) \text {, patient decision }(26 \%) \text {, } \\
\text { AEs }(21 \%)\end{array}$ \\
\hline $\begin{array}{l}\text { EAP analysis } \\
\left(\text { Chang et } \mathrm{al}^{71}\right)\end{array}$ & $\begin{array}{l}\text { Open-label, multicenter study: } \\
\text { Advanced BCC }{ }^{\mathrm{a}} \\
\text { Vismodegib } 150 \mathrm{mg} \text { QD n=II9 } \\
\text { ( } 62 \text { laBCC and } 57 \mathrm{mBCC} \text { patients) }\end{array}$ & $\begin{array}{l}\text { - ORR (local review): } 46.4 \% \text { (laBCC) } \\
\text { and } 30.8 \% \text { (mBCC) } \\
\text { PFS and DOR not assessed due } \\
\text { to limited follow-up (median of } \\
6.5 \text { months for safety) }\end{array}$ & $\begin{array}{l}\text { Frequent any-grade AEs: muscle spasms } \\
(71 \%) \text {, dysgeusia (7I\%), alopecia ( } 58 \%) \text {, } \\
\text { diarrhea ( } 25 \%) \text {, fatigue (19\%), nausea } \\
\text { (19\%), weight loss (16\%) } \\
\text { Reason for treatment discontinuation: } \\
\text { switch to commercial product ( } 66 \%), P D \\
(13 \%), \text { AEs }(4 \%) \text {, patient decision }(6 \%)\end{array}$ \\
\hline STEVIE ${ }^{51,69}$ & $\begin{array}{l}\text { Phase II, single-arm, multicenter, } \\
\text { open-label, safety study: } \\
\text { Advanced BCC } \\
\text { Vismodegib } 150 \mathrm{mg} \text { QD } \mathrm{n}=1,215 \\
\text { (I,I I } 9 \text { laBCC and } 96 \mathrm{mBCC} \text { patients) }\end{array}$ & $\begin{array}{l}\text { - ORR (local review): 68.5\% (laBCC) } \\
\text { and } 36.9 \% \text { (mBCC) } \\
\text { - PFS: } 23.2 \text { (laBCC) and I3.I (mBCC) } \\
\text { months } \\
\text { - DOR: } 23.0 \text { (laBCC) and I3.9 months } \\
\text { (mBCC) }\end{array}$ & $\begin{array}{l}\text { Frequent any-grade AEs: muscle spasms } \\
(66 \%) \text {, alopecia }(62 \%) \text {, dysgeusia ( } 55 \%) \text {, } \\
\text { weight loss ( } 41 \%) \text {, nausea (18\%), fatigue } \\
(16 \%) \text {, diarrhea }(16 \%) \\
\text { Reason for treatment discontinuation: } \\
\text { AEs ( } 31 \%) \text {, others not reported }\end{array}$ \\
\hline $\mathrm{MIKIE}^{78}$ & $\begin{array}{l}\text { Phase II, randomized, controlled, } \\
\text { double-blind trial: } \\
\text { Patients with multiple ( } \geq 6 \text { ) BCCs } \\
\mathrm{N}=229 \text { ( } 85 \text { patients with basal cell } \\
\text { nevus syndrome) } \\
\text { Group A: vismodegib } 150 \mathrm{mg} \text { QD for } \\
12 \text { weeks, then } 3 \text { cycles of } 8 \text { weeks } \\
\text { placebo and I } 2 \text { weeks vismodegib } \\
\text { Group B: vismodegib I } 50 \text { mg QD for } \\
24 \text { weeks, then } 3 \text { cycles of } 8 \text { weeks } \\
\text { placebo and } 8 \text { weeks vismodegib }\end{array}$ & $\begin{array}{l}\text { - Reduction of mean number } \\
\text { of BCCs at week } 73: 62.7 \% \text { in } \\
\text { treatment group A (9.8-3.4 lesions) } \\
\text { and } 54.0 \% \text { in treatment group B } \\
\text { (9.I-3.5 lesions) } \\
\text { - Patients without new BCCs at the } \\
\text { end of treatment: } 72 \text { of } 94(77 \%) \\
\text { in group A and } 64 \text { of } 86(74.4 \%) \text { in } \\
\text { group B }\end{array}$ & $\begin{array}{l}\text { Frequent any-grade AEs (group A/B): } \\
\text { muscle spasms }(69 / 72 \%) \text {, dysgeusia } \\
(65 / 65 \%) \text {, alopecia }(63 / 65 \%) \text {, fatigue } \\
(21 / 23 \%) \text {, weight loss }(20 / 19 \%) \text {, nausea } \\
(20 / 12 \%) \text {, diarrhea }(18 / 15 \%) \\
\text { Reason for treatment discontinuation: } \\
\text { AEs (group A: } 20 \% \text {, group B: } 27 \%) \text {, } \\
\text { patient decision (group A: } 10 \% \text {, group B: } \\
\text { I2\%), PD ( } 2.6 \% \text { in both groups) }\end{array}$ \\
\hline
\end{tabular}

Note: aAdvanced BCC: either laBCC or $\mathrm{mBCC}$ not amenable for surgery or radiotherapy.

Abbreviations: AE, adverse event; $B C C$, basal cell carcinoma; DOR, duration of response; $E A P$, expanded access program; laBCC, locally advanced $B C C$; mBCC, metastatic BCC; ORR, overall response rate; PD, progressive disease; PFS, progression-free survival; QD, once daily.

reported in a total of three patients with $\mathrm{mBCC}$. By univariate analysis, prior systemic therapy was found to reduce the probability of response to vismo in patients with laBCC in this study ( $P=0.002$ ). Contrary to the ERIVANCE study, median time to objective response was similar in $\mathrm{mBCC}$ and laBCC cohorts (2.6 months in both). Mean follow-up of this study was only 6.5 months, as it was terminated, once vismo was commercially available. During this limited follow-up period, the safety profile of vismo concerning the frequency and character of treatment-related AEs was similar to the ERIVANCE study.

To further assess the safety of vismo treatment, in 2011 , the STEVIE study was initiated (Table 1). ${ }^{54,72}$ In this singlearm, open-label, Phase II trial, 1,215 patients (1,119 with laBCC and 96 with $\mathrm{mBCC}$ ) were treated with the standard dose of vismo continuously until disease progression, death, unacceptable toxicity or other reasons for discontinuation. Results of both an interim and the primary analysis of the trial have been published. ${ }^{54,72}$ The primary end point of the trial was safety. Ninety-eight percent of patients in this large-scale study experienced at least one AE related to vismo treatment. The most common AEs were in line with previous studies and are summarized in Table 2. Unlike suggested by the results of the ERIVANCE trial, no increase in frequency or severity of AEs with increased time on treatment could be shown in the STEVIE trial. After a median follow-up of 17.9 months, $31 \%$ of patients (380) discontinued vismo treatment owing to AEs. These AEs were mostly low grade (Common Toxicity Criteria [CTC] grade 1 or 2) and included muscle spasm, dysgeusia, weight loss, alopecia, decreased appetite, asthenia, fatigue, ageusia and nausea in decreasing frequency. Within 12 months after treatment discontinuation, 54.5\% of patients were free of any AEs, demonstrating the reversibility of most vismo-related AEs. Of note, the incidence of cutaneous squamous cell carcinoma (SCC) was $4.2 \%$ in the STEVIE study, which is comparable to the incidence in the 
Table 2 Overview of selected treatment-related AEs in the STEVIE trial $(n=I, 2 \mid 5)^{54}$

\begin{tabular}{|l|l|l|l|}
\hline Type of AE/CTC grade & Any grade (n (\%)) & Grade I-2 (n (\%)) & Grade 3-4 (n (\%)) \\
\hline Muscle spasms & $807(66.4)$ & $712(58.6)$ & $95(7.8)$ \\
Alopecia & $747(61.5)$ & $731(60.2)$ & $16(1.3)$ \\
Dysgeusia & $663(54.6)$ & $637(52.4)$ & $26(2.1)$ \\
Weight loss & $493(40.6)$ & $444(36.5)$ & $48(4.0)$ \\
Decreased appetite & $303(24.9)$ & $283(23.3)$ & $20(1.6)$ \\
Asthenia* & $291(24.0)$ & $267(22.0)$ & $23(1.9)$ \\
Nausea & $218(17.9)$ & $214(17.6)$ & $4(0.3)$ \\
Ageusia & $213(17.5)$ & $197(16.2)$ & $16(1.3)$ \\
Fatigue & $201(16.5)$ & $181(14.9)$ & $20(1.6)$ \\
Diarrhoea & $197(16.2)$ & $189(15.6)$ & $8(0.7)$ \\
Arthralgia & $124(10.2)$ & $120(9.9)$ & $4(0.3)$ \\
Constipation & $116(9.5)$ & $99(8.1)$ & $2(0.2)$ \\
Vomiting & $102(8.4)$ & $89(7.3)$ & $3(0.2)$ \\
Headache & $92(7.6)$ & $71(5.8)$ & $3(0.2)$ \\
Anaemia & $89(7.3)$ & $74(6.1)$ & $18(1.5)$ \\
Myalgia & $81(6.7)$ & $46(3.8)$ & $7(0.6)$ \\
Increased CPK & $60(4.9)$ & $28(2.3)$ & $14(1.2)$ \\
Increased GGT & $58(4.8)$ & $49(4.0)$ & $30(2.5)$ \\
Increased AST & $56(4.6)$ & $44(3.6)$ & $7(0.6)$ \\
Increased ALT & $56(4.6)$ & $55(4.5)$ & $12(1.0)$ \\
Rash & $55(4.5)$ & $23(1.9)$ & 0 \\
Cutaneous SCC* & $38(3.1)$ & $12(1.0)$ \\
\hline Abrev & & $1.9)$ \\
\hline
\end{tabular}

Abbreviations: AE, adverse event; ALT, alanine aminotransferase; AST, aspartate aminotransferase; CPK, creatine phosphokinase; CTC, Common Toxicity Criteria; GGT, gamma-glutamyltransferase; SCC, squamous cell carcinoma. *One patient with asthenia and three patients with cutaneous SCC experienced a CTC grade 5 adverse event (death).

age-matched general population. Hence, an increased risk of SCC development in patients treated with vismo which has been previously proposed, for example, by Orouji et al ${ }^{73}$ and Mohan et al, ${ }^{74}$ was not confirmed in the STEVIE trial. This is in line with a recent retrospective analysis including 1,675 patients. $^{75}$ Among the patients, 1,161 were evaluable for response to treatment in the STEVIE trial. Investigatorassessed ORR was $68.5 \%$ in $1 \mathrm{laBCC}$ and $36.9 \%$ in $\mathrm{mBCC}$ patients. ${ }^{54}$ Similar to the ERIVANCE trial, median DOR appeared to be shorter in metastatic than in locally advanced disease (13.9 vs 23.0 months). A total of 219 patients (18.1\%) with Gorlin syndrome were enrolled in the STEVIE trial. The ORR in this subgroup was $81.7 \%$ and $80.0 \%$ in patients with $\mathrm{laBCC}$ and $\mathrm{mBCC}$, respectively. In addition, the rate of complete responses was higher in patients with Gorlin syndrome than in the overall study population $(45.1 \%$ vs $28.2 \%$ ). The authors attributed these differences in response to the younger age and better performance status of patients with Gorlin syndrome, but further research seems necessary to address these findings.

Tang et al investigated vismo in a different setting in patients with Gorlin syndrome. ${ }^{76}$ These authors conducted a randomized, double-blind trial comparing vismo with placebo in Gorlin patients with at least ten surgically eligible primary BCCs. Patients could receive vismo treatment for up to 36 months. Efficacy in patients with multiple BCCs was excellent, as all patients treated with vismo experienced a reduction in the sum of the total lesion size. Moreover, vismo treatment led to a significant reduction in the appearance of new BCCs compared to placebo. However, only five of all 40 patients in the trial who received vismo tolerated treatment without a treatment break due to AEs. Drug discontinuation, in turn, was shown to increase the appearance of new BCCs again and also led to reappearance of initially present BCCs in some cases. Although a positive long-term effect of intermittent vismo treatment on the incidence of BCC in Gorlin syndrome patients was suggested, improvement of vismo tolerability remains crucial. Specific AE management guidelines have been published in this context, which for example recommend the administration of amlodipine for the treatment of hedgehog inhibitor-associated muscle spasms. ${ }^{77}$

Along these lines - in order to improve tolerability of vismo treatment - the MIKIE trial was initiated (Table 1). ${ }^{78}$ This 1:1 randomized, double-blind Phase II trial compared different intermittent dosing regimens of vismo in patients with multiple primary BCCs. In this trial, 229 patients with at least six clinically evident BCCs were enrolled. Patients randomized to group A received $150 \mathrm{mg}$ vismo per day 
for 12 weeks followed by an 8-week treatment break per cycle. Treatment was terminated after the vismo phase of the fourth cycle, resulting in a total treatment duration of 72 weeks. Patients in group B received vismo for 24 weeks initially, followed by an 8-week-off, 8-week-on treatment schedule, also until 72 weeks of treatment duration had been reached. Thereafter, a follow-up period of 52 weeks started. According to the primary analysis of the MIKIE trial, at week 73, the mean number of BCCs was reduced from baseline by $62.7 \%$ in treatment group A and $54.0 \%$ in treatment group B. This difference did not reach statistical significance in an exploratory analysis. A significant difference between treatment groups in this regard was only reported in the subgroup of patients without Gorlin syndrome (72 patients in each group). Frequency of BCC recurrence after treatment termination was not reported in the primary analysis due to limited follow-up. Frequency and character of vismo-related AEs with intermittent dosing were similar in both treatment arms and generally comparable to continuous dosing trials such as STEVIE. However, intermittent dosing appears to be associated with the appearance of fewer CTC grade 3 or 4 AEs (31\% of patients in the MIKIE vs $44 \%$ in the STEVIE study). ${ }^{54,78}$ Treatment exposure may also improve with intermittent treatment, as $23 \%$ of patients in the MIKIE population discontinued treatment due to AEs (compared to $31 \%$ in the STEVIE trial). In group A of the MIKIE trial, this percentage was even lower ( $19.8 \%$ or $23 / 116$ patients). The authors concluded that both intermittent treatment regimens investigated in the MIKIE appear to be equally effective and tolerable and hence may present a valuable strategy in patients with multiple BCCs requiring long-term treatment with vismo.

An emerging alternative treatment strategy utilizing vismo is the neoadjuvant setting. In 2013, Chang et al reported a first case of successful neoadjuvant vismo therapy before surgical excision of a large laBCC on the scalp of a patient with Gorlin syndrome. ${ }^{79}$ Most recently, Mortier et al presented the first results of a multicenter neoadjuvant trial with vismo (VISMONEO), including 55 patients with laBCC. ${ }^{80}$ The mean size of the target lesion in this study was $47.3 \mathrm{~mm}$. Patients received continuous vismo treatment until for a period of up to 10 months until best response was reached. Eighty percent of patients (44) in the study cohort reached the primary end point downstaging of surgical procedure. Twenty-seven patients (49.1\%) achieved a clinical complete response. Twenty-five of these complete responses were proven histologically by biopsy. Follow-up data will be necessary to confirm the durability of responses reported in this trial. This may determine whether neoadjuvant vismo treatment can lead to long-term disease control and make avoidance of extensive surgery in selected patients possible.

\section{Overview on the benefit-to-risk profile of vismo and potential for combination treatments}

laBCCs, which have either progressed to an inoperable state or metastasized can be often disfiguring or debilitating and frequently affect the psychological state and quality of life (QoL) of patients. ${ }^{81}$ Especially, the size and the number of lesions have been found to have an important impact on QoL. The durable reduction in size of tumor lesions after vismo treatment was considered as a clinical benefit and led to the approval of vismo for the treatment of laBCC by the FDA. ${ }^{82}$ Further analysis of the pivotal ERIVANCE BCC trial showed that $76.2 \%$ of the patients benefitted from the treatment with clinically meaningful and durable responses, ${ }^{83}$ which is regardless of age. ${ }^{84} \mathrm{~A}$ recent review also speculates about a possible survival benefit of patients with $\mathrm{mBCC}$ with vismo treatment. ${ }^{85}$ Although intracranial invasion of $\mathrm{BCC}$ is rare, those patients may also benefit from vismo treatment. ${ }^{86,87}$ Moreover, vismo has been successfully used to treat immunosuppressed patients with solid organ transplants, who have an increased risk to develop cutaneous malignancies. ${ }^{88,89}$

One of the major limitations in the use of vismo is the occurrence of treatment-emergent AEs leading to lower treatment adherence and discontinuation of therapy. As stated earlier, nearly all patients treated with vismo experience at least one treatment-emergent AE. ${ }^{77}$ Although the majority of AEs associated with vismo are usually of low grade, 46 fatalities $(3.8 \%)$ were reported as related to vismo treatment in the STEVIE trial. ${ }^{72}$

The debate about the association of vismo treatment with an increased risk to develop cutaneous SCC has been addressed earlier. SCC can either arise in histologically confirmed BCCs resistant to vismo or arise in areas separate from the treated BCCs. ${ }^{90-92}$ Besides SCC, fast-growing melanoma following vismo treatment has also been reported in two patients, which clearly warrants further investigation concerning its clinical significance. ${ }^{93}$ Clinicians should also be aware of possible hepatotoxicity associated with vismo therapy. ${ }^{94}$ Although it is unclear whether the observed hepatotoxicity is directly attributable to vismo or the result of drug-drug interactions between vismo and other concomitant medications, ${ }^{95-97}$ it is currently recommended that 
the concurrent use of vismo and medication interfering with hepatic metabolism should be avoided..$^{98}$ Concerning other rare AEs, also isolated cases of potentially life-threatening skin conditions such as drug reaction with eosinophilia and systemic symptoms or acute generalized exanthematous pustolosis have been reported to be associated with vismo. ${ }^{99,100}$

In clinical practice, one key challenge is to overcome either primary (intrinsic) resistance to vismo (BCCs not at all responding to treatment) as observed by $\mathrm{Zhu}$ et $\mathrm{al}^{101}$ or secondary (acquired) resistance (tumor initially responding to vismo) as reported by Chang and Oro. ${ }^{102}$

Mutations in smoothened, frizzled class receptor (SMO) confer resistance to vismo in at least $50 \%$ of refractory BCCs, which is why other targets downstream of SMO have been proposed as further therapeutic options. ${ }^{103}$ Due to the cross talk between the hedgehog and other signaling pathways, a combination of vismo with other pathway inhibitors could synergistically lead to enhanced tumor elimination. ${ }^{104}$ Data from experiments in mice suggest the SOX9-mTOR axis as such a potential additional target. ${ }^{105}$ This is further supported by a recent case report where concomitant application of vismo and the mTOR inhibitor everolimus led to a successful eradication of a locally destructive BCC without significantly increased toxicity. ${ }^{89}$ However, future clinical trials are needed to determine the clinical benefit of this combination. Another potential combinatorial approach could be the addition of epidermal growth fact receptor (EGFR) inhibitors to vismo, since the combined inhibition of EGFR and hedgehog signaling significantly reduced the growth of mouse BCC cell lines in vitro. ${ }^{106}$ The simultaneous inhibition of the hedgehog pathway and histone deacetylase has been proposed as another strategy to overcome vismo resistance in laBCC. ${ }^{107}$

The observation that a proportion of BCCs express PD-L1 and that resistance to hedgehog inhibition can be hindered by anti-PD-1 therapy provides a rationale for combination of vismo and PD-1 pathway blockage. ${ }^{61}$ The potential of this combination is currently assessed as part of a clinical trial already mentioned earlier in this review (NTC02690948).

Vismo treatment can be combined not only with other systemic treatments but also with conventional treatment options such as surgery or RT. Besides the previously discussed neoadjuvant approach combining vismo treatment with surgery, two clinical trials are currently investigating the concurrent use of vismo and radiation therapy (NCT01835626 and NCT02956889). Thus far, this strategy has been described to be feasible in several case reports. ${ }^{108-110}$ Alternative to RT, vismo treatment may also be combined with other nonsurgical treatments such as PDT, as recently reported by Rizzo et al. ${ }^{111}$

\section{Patient-focused perspectives such as QoL}

Especially, the basal cell nevus (Gorlin) syndrome has a substantial influence on the QoL and is linked to an increased frequency of depressive symptoms. ${ }^{112}$ Due to possible disfigurement and prolonged recovery time, invasive treatments such as surgery may have a greater impact on QoL and negatively affect psychological well-being than noninvasive treatments. ${ }^{112}$ Therefore, vismo treatment could possibly improve QoL of these patients, as vismo has proven to be specifically efficacious in patients with Gorlin syndrome both in the study by Tang et al and the MIKIE trial. ${ }^{76,78}$ The decreased rate of treatment discontinuations observed with intermittent dosing could possibly reflect that in patients with multiple BCCs the long-term gain of treatment may outweigh the impact of treatment-related AEs.

Side effects of vismo clearly decrease QoL and limit long-term treatment, but they resolve after discontinuation of therapy within different time frames. ${ }^{113}$ Muscle spasms, which usually occur early during treatment, are the most frequently observed AE during vismo therapy and greatly impact treatment adherence and outcome. ${ }^{77}$ Patients with Gorlin syndrome seem to suffer more frequently from muscle spasms than patients with laBCC. ${ }^{54}$ In a prospective study with 30 patients with BCC, vismo-induced muscle cramps were mostly experienced in lower limbs at night time, subsequently affecting daily activities. ${ }^{114}$ Adequate hydration and muscle stretching may be an effective management strategy to improve vismo-induced muscle cramps. ${ }^{114}$ The frequency of muscle spasms during vismo treatment may be alleviated by the use of calcium channel blockers or cannabis. ${ }^{115-117}$ Recently, a small randomized, double-blind, placebo-controlled trial has demonstrated the efficacy of the dietary supplement levocarnitine to significantly reduce not only the frequency of muscle spasms but also the number of body locations affected by vismo-induced muscle spasms. ${ }^{118}$ Quinine and muscle relaxants such as cyclobenzaprine may also be used to alleviate muscle cramps caused by vismo treatment. ${ }^{113,119}$

Hedgehog signaling is not only involved in the pathogenesis of BCC but also implicated in the morphogenesis and function of hair follicles. ${ }^{120}$ Therefore, it is not surprising that alopecia has been reported in over $60 \%$ of patients with BCC across clinical trials with vismo. ${ }^{54,78,113}$ Of note, patients with Gorlin syndrome seem to be affected by alopecia more often than patients with laBCC. ${ }^{54}$ The hair loss observed with 
vismo is typically gradual and may not only affect the head but also other body hair such as eyebrows and eyelashes. ${ }^{113}$ Although vismo-induced alopecia is typically resolving within 6-12 months after treatment discontinuation, it may be prolonged in some cases. ${ }^{13,121}$ Particularly in women, vismoinduced alopecia may lead to lower self-esteem, poorer body image and lower QoL as shown for cancer in general. ${ }^{122}$

The hedgehog pathway is also a regulator of the formation and maintenance of taste buds. ${ }^{123}$ Since vismo directly alters molecular signaling in taste buds, ${ }^{124}$ it is not unexpected that taste disturbances (dysgeusia/ageusia) occur in more than $50 \%$ of BCC patients treated with vismo. ${ }^{54,78,113}$ Taste disturbances typically develop within the first months of treatment and often make changes in the daily diet of patients necessary. Furthermore, they may cause weight loss, anorexia and depression. ${ }^{113}$ Besides decreased appetite and weight loss, which can be linked to taste alterations, asthenia has been reported as one of the most common side effects of vismo, occurring in over $20 \%$ of patients in the STEVIE trial. ${ }^{54}$ Interestingly, in patients with Gorlin syndrome, diarrhea, nausea and fatigue are also listed among the most common treatment-emergent AEs associated with vismo in this trial. ${ }^{54}$ Since vismo is teratogenic in animals and can result in embryo-fetal death or severe birth defects, ${ }^{125}$ effective methods of contraception under vismo therapy are mandatory both for male and female patients of reproductive age.

\section{Conclusion - place in therapy}

Since its regulatory approval more than 5 years ago, vismo has become an established treatment option for patients with advanced BCC in clinical practice. However, certain limitations of vismo treatment should be kept in mind. The inevitably occurring side effects of vismo lead to a significant rate of treatment discontinuation limiting overall drug exposure. Hence, long-term continuous treatment with vismo is not feasible in most patients. Clinical end points which may help to determine the optimal treatment duration (lifelong/ continuous treatment vs treatment until best response) are lacking. Alternative dosing regimens, such as those investigated in the MIKIE trial, ${ }^{78}$ may improve tolerability and dose exposure potentially enhancing the drug's therapeutic value. Improved drug tolerability is particularly important in situations that require long-term treatment, for example, patients with the basal cell nevus syndrome who repeatedly develop multiple BCCs over decades.

In advanced $\mathrm{BCC}$, in turn, neoadjuvant vismo treatment may be increasingly integrated into the multimodality therapeutic approach that is individually determined for every patient. This requires that the responses seen after neoadjuvant therapy in the VISMONEO trial ${ }^{80}$ prove to be durable and thorough, as development of skip lesions is conceivable with adjuvant vismo treatment and needs to be excluded. Alternative or adjunct to vismo therapy in advanced BCC, other systemic treatment approaches, such as PD-1- or PD-L1 antibody-based immunotherapy, may gain more and more importance as ongoing clinical trials progress.

Yet, clinicians should keep in mind that the vast majority of BCCs can be cured by relatively simple surgical or nonsurgical methods. These do also appear superior to systemic treatment with vismo or other hedgehog inhibitors in terms of cost-effectiveness, although comparative studies are missing. Skin cancer-screening programs and measures to raise the awareness of UV protection and skin cancer in the general population should enable early detection of most BCCs and hence avoid an increase in the absolute numbers of patients requiring systemic therapy for $\mathrm{BCC}$ in the future.

\section{Disclosure}

PK has received honoraria and travel grants from Roche unrelated to the present article. RL has received honoraria, travel grants and a research grant from Roche unrelated to the present article. The authors report no other conflicts of interest in this work.

\section{References}

1. Peterson SC, Eberl M, Vagnozzi AN, et al. Basal cell carcinoma preferentially arises from stem cells within hair follicle and mechanosensory niches. Cell Stem Cell. 2015;16(4):400-412.

2. Richmond-Sinclair NM, Pandeya N, Ware RS, et al. Incidence of basal cell carcinoma multiplicity and detailed anatomic distribution: longitudinal study of an Australian population. J Invest Dermatol. 2009;129(2): 323-328.

3. Wu S, Han J, Li WQ, Li T, Qureshi AA. Basal-cell carcinoma incidence and associated risk factors in U.S. women and men. Am J Epidemiol. 2013; 178(6):890-897.

4. Verkouteren JAC, Ramdas KHR, Wakkee M, Nijsten T. Epidemiology of basal cell carcinoma: scholarly review. Br J Dermatol. 2017;177(2): 359-372.

5. Lomas A, Leonardi-Bee J, Bath-Hextall F. A systematic review of worldwide incidence of nonmelanoma skin cancer. Br J Dermatol. 2012; 166(5):1069-1080.

6. Staples MP, Elwood M, Burton RC, Williams JL, Marks R, Giles GG. Non-melanoma skin cancer in Australia: the 2002 national survey and trends since 1985. Med J Aust. 2006;184(1):6-10.

7. Rosso S, Zanetti R, Martinez C, et al. The multicentre south European study 'Helios'. II: Different sun exposure patterns in the aetiology of basal cell and squamous cell carcinomas of the skin. Br J Cancer. 1996;73(11): $1447-1454$.

8. van Dam RM, Huang Z, Rimm EB, et al. Risk factors for basal cell carcinoma of the skin in men: results from the health professionals follow-up study. Am J Epidemiol. 1999;150(5):459-468.

9. Asgari MM, Moffet HH, Ray GT, Quesenberry CP. Trends in Basal Cell Carcinoma Incidence and Identification of High-Risk Subgroups, 1998-2012. JAMA Dermatol. 2015;151(9):976-981. 
10. Bonilla X, Parmentier L, King B, et al. Genomic analysis identifies new drivers and progression pathways in skin basal cell carcinoma. Nat Genet. 2016;48(4):398-406.

11. Hahn H, Wicking C, Zaphiropoulous PG, et al. Mutations of the human homolog of Drosophila patched in the nevoid basal cell carcinoma syndrome. Cell. 1996;85(6):841-851.

12. von Hoff DD, Lorusso PM, Rudin CM, et al. Inhibition of the hedgehog pathway in advanced basal-cell carcinoma. NEngl J Med. 2009;361(12): 1164-1172.

13. Pellegrini C, Maturo MG, di Nardo L, Ciciarelli V, Gutiérrez GarcíaRodrigo C, Fargnoli MC. Understanding the Molecular Genetics of Basal Cell Carcinoma. Int J Mol Sci. 2017;18(11):2485.

14. Trakatelli M, Morton C, Nagore E, et al. Update of the European guidelines for basal cell carcinoma management. Eur J Dermatol. 2014; 24(3):312-329.

15. Dandurand M, Petit T, Martel P, Guillot B; ANAES. Management of basal cell carcinoma in adults Clinical practice guidelines. Eur $J$ Dermatol. 2006;16(4):394-401.

16. Wolf DJ, Zitelli JA. Surgical margins for basal cell carcinoma. Arch Dermatol. 1987;123(3):340-344.

17. Gulleth Y, Goldberg N, Silverman RP, Gastman BR. What is the best surgical margin for a Basal cell carcinoma: a meta-analysis of the literature. Plast Reconstr Surg. 2010;126(4):1222-1231.

18. Silverman MK, Kopf AW, Bart RS, Grin CM, Levenstein MS. Recurrence rates of treated basal cell carcinomas. Part 3: Surgical excision. J Dermatol Surg Oncol. 1992;18(6):471-476.

19. Rowe DE, Carroll RJ, Day CL. Mohs surgery is the treatment of choice for recurrent (previously treated) basal cell carcinoma. J Dermatol Surg Oncol. 1989;15(4):424-431.

20. Rowe DE, Carroll RJ, Day CL. Long-term recurrence rates in previously untreated (primary) basal cell carcinoma: implications for patient follow-up. J Dermatol Surg Oncol. 1989;15(3):315-328.

21. National Comprehensive Cancer Network. NCCN Clinical Practice Guidelines in Oncology: Basal Cell Carcinoma. 2018. Available from: https://www.nccn.org/professionals/physician_gls/pdf/nmsc.pdf. Accessed November 15, 2018.

22. Mosterd K, Krekels GA, Nieman FH, et al. Surgical excision versus Mohs' micrographic surgery for primary and recurrent basal-cell carcinoma of the face: a prospective randomised controlled trial with 5-years' follow-up. Lancet Oncol. 2008;9(12):1149-1156.

23. Kopf AW, Bart RS, Schrager D, Lazar M, Popkin GL. Curettageelectrodesiccation treatment of basal cell carcinomas. Arch Dermatol. 1977;113(4):439-443.

24. Kuflik EG. Cryosurgery for skin cancer: 30-year experience and cure rates. Dermatol Surg. 2004;30(2 Pt 2):297-300.

25. Jaramillo-Ayerbe F. Cryosurgery in difficult to treat basal cell carcinoma. Int J Dermatol. 2000;39(3):223-229.

26. Geisse J, Caro I, Lindholm J, Golitz L, Stampone P, Owens M. Imiquimod $5 \%$ cream for the treatment of superficial basal cell carcinoma: results from two phase III, randomized, vehicle-controlled studies. J Am Acad Dermatol. 2004;50(5):722-733.

27. Gollnick H, Barona CG, Frank RG, et al. Recurrence rate of superficial basal cell carcinoma following treatment with imiquimod 5\% cream: conclusion of a 5-year long-term follow-up study in Europe. Eur J Dermatol. 2008;18(6):677-682.

28. Quirk C, Gebauer K, de'ambrosis B, Slade HB, Meng TC. Sustained clearance of superficial basal cell carcinomas treated with imiquimod cream 5\%: results of a prospective 5-year study. Cutis. 2010;85(6): 318-324.

29. Jansen MHE, Mosterd K, Arits A, et al. Five-Year Results of a Randomized Controlled Trial Comparing Effectiveness of Photodynamic Therapy, Topical Imiquimod, and Topical 5-Fluorouracil in Patients with Superficial Basal Cell Carcinoma. J Invest Dermatol. 2018;138(3):527-533.

30. Siller G, Rosen R, Freeman M, Welburn P, Katsamas J, Ogbourne SM. PEP005 (ingenol mebutate) gel for the topical treatment of superficial basal cell carcinoma: results of a randomized phase IIa trial. Australas J Dermatol. 2010;51(2):99-105.
31. Izzi S, Sorgi P, Piemonte P, Carbone A, Frascione P. Successfully treated superficial basal cell carcinomas with ingenol mebutate $0.05 \%$ gel: Report of twenty cases. Dermatol Ther. 2016;29(6):470-472.

32. Iannazzone SS, Ingordo V. Nodular basal cell carcinoma of the face successfully treated with ingenol mebutate $0.015 \%$ gel. Dermatol Pract Concept. 2018;8(2):129-131.

33. Kuijpers DI, Thissen MR, Thissen CA, Neumann MH. Similar effectiveness of methyl aminolevulinate and 5-aminolevulinate in topical photodynamic therapy for nodular basal cell carcinoma. J Drugs Dermatol. 2006;5(7):642-645.

34. Basset-Seguin N, Ibbotson SH, Emtestam L, et al. Topical methyl aminolaevulinate photodynamic therapy versus cryotherapy for superficial basal cell carcinoma: a 5 year randomized trial. Eur J Dermatol. 2008;18(5):547-553.

35. Szeimies RM, Ibbotson S, Murrell DF, et al. A clinical study comparing methyl aminolevulinate photodynamic therapy and surgery in small superficial basal cell carcinoma (8-20 mm), with a 12-month follow-up. J Eur Acad Dermatol Venereol. 2008;22(11):1302-1311.

36. Fantini F, Greco A, del Giovane C, et al. Photodynamic therapy for basal cell carcinoma: clinical and pathological determinants of response. J Eur Acad Dermatol Venereol. 2011;25(8):896-901.

37. Rhodes LE, de Rie MA, Leifsdottir R, et al. Five-year follow-up of a randomized, prospective trial of topical methyl aminolevulinate photodynamic therapy vs surgery for nodular basal cell carcinoma. Arch Dermatol. 2007;143(9):1131-1136.

38. Morton CA, Braathen LR. Daylight Photodynamic Therapy for Actinic Keratoses. Am J Clin Dermatol. 2018;19(5):647-656.

39. Wiegell SR, Haedersdal M, Philipsen PA, Eriksen P, Enk CD, Wulf HC. Continuous activation of PpIX by daylight is as effective as and less painful than conventional photodynamic therapy for actinic keratoses; a randomized, controlled, single-blinded study. Br J Dermatol. 2008; 158(4):740-746.

40. Sotiriou E, Evangelou G, Papadavid E, et al. Conventional vs. daylight photodynamic therapy for patients with actinic keratosis on face and scalp: 12-month follow-up results of a randomized, intra-individual comparative analysis. J Eur Acad Dermatol Venereol. 2018;32(4): 595-600.

41. Fargnoli MC, Piccioni A, Neri L, Tambone S, Pellegrini C, Peris K. Conventional vs. daylight methyl aminolevulinate photodynamic therapy for actinic keratosis of the face and scalp: an intra-patient, prospective, comparison study in Italy. J Eur Acad Dermatol Venereol. 2015;29(10): 1926-1932.

42. Wiegell SR, Skødt V, Wulf HC. Daylight-mediated photodynamic therapy of basal cell carcinomas - an explorative study. J Eur Acad Dermatol Venereol. 2014;28(2):169-175.

43. Zagrodnik B, Kempf W, Seifert B, et al. Superficial radiotherapy for patients with basal cell carcinoma: recurrence rates, histologic subtypes, and expression of p53 and Bcl-2. Cancer. 2003;98(12): 2708-2714.

44. Cognetta AB, Howard BM, Heaton HP, Stoddard ER, Hong HG, Green WH. Superficial x-ray in the treatment of basal and squamous cell carcinomas: a viable option in select patients. $J$ Am Acad Dermatol. 2012;67(6):1235-1241.

45. Avril MF, Auperin A, Margulis A, et al. Basal cell carcinoma of the face: surgery or radiotherapy? Results of a randomized study. $\mathrm{Br} J$ Cancer. 1997;76(1):100-106.

46. Strom T, Harrison LB. Radiotherapy for management of basal and squamous cell carcinoma. Curr Probl Cancer. 2015;39(4):237-247.

47. Nguyen-Nielsen M, Wang L, Pedersen L, et al. The incidence of metastatic basal cell carcinoma (mBCC) in Denmark, 1997-2010. Eur J Dermatol. 2015;25(5):463-468.

48. Moeholt K, Aagaard H, Pfeiffer P, Hansen O. Platinum-based cytotoxic therapy in basal cell carcinoma - a review of the literature. Acta Oncol. 1996;35(6):677-682.

49. Carneiro BA, Watkin WG, Mehta UK, Brockstein BE. Metastatic basal cell carcinoma: complete response to chemotherapy and associated pure red cell aplasia. Cancer Invest. 2006;24(4):396-400. 
50. Rodon J, Tawbi HA, Thomas AL, et al. A phase I, multicenter, openlabel, first-in-human, dose-escalation study of the oral smoothened inhibitor Sonidegib (LDE225) in patients with advanced solid tumors. Clin Cancer Res. 2014;20(7):1900-1909.

51. Migden MR, Lewis KD. 42-month follow-up of sonidegib efficacy and safety in advanced basal cell carcinoma: Final analysis from BOLT. J Clin Oncol. 2018;36(15 Suppl):9551.

52. Migden MR, Guminski A, Gutzmer R, et al. Treatment with two different doses of sonidegib in patients with locally advanced or metastatic basal cell carcinoma (BOLT): a multicentre, randomised, double-blind phase 2 trial. Lancet Oncol. 2015;16(6):716-728.

53. Sekulic A, Migden MR, Basset-Seguin N, et al. Long-term safety and efficacy of vismodegib in patients with advanced basal cell carcinoma: final update of the pivotal ERIVANCE BCC study. BMC Cancer. 2017; 17(1):332.

54. Basset-Séguin N, Hauschild A, Kunstfeld R, et al. Vismodegib in patients with advanced basal cell carcinoma: Primary analysis of STEVIE, an international, open-label trial. Eur J Cancer. 2017;86:334-348.

55. Lear JT, Migden MR, Lewis KD, et al. Long-term efficacy and safety of sonidegib in patients with locally advanced and metastatic basal cell carcinoma: 30-month analysis of the randomized phase 2 BOLT study. J Eur Acad Dermatol Venereol. 2018;32(3):372-381.

56. Wahid M, Jawed A, Dar SA, Mandal RK, Haque S. Differential pharmacology and clinical utility of sonidegib in advanced basal cell carcinoma. Onco Targets Ther. 2017;10:515-520.

57. Jayaraman SS, Rayhan DJ, Hazany S, Kolodney MS. Mutational landscape of basal cell carcinomas by whole-exome sequencing. J Invest Dermatol. 2014;134(1):213-220.

58. Fischer S, Ali OH, Jochum W, Kluckert T, Flatz L, Siano M. Anti-PD-1 Therapy Leads to Near-Complete Remission in a Patient with Metastatic Basal Cell Carcinoma. Oncol Res Treat. 2018;41(6):391-394.

59. Cannon JGD, Russell JS, Kim J, Chang ALS. A case of metastatic basal cell carcinoma treated with continuous PD-1 inhibitor exposure even after subsequent initiation of radiotherapy and surgery. JAAD Case Rep. 2018;4(3):248-250.

60. Moreira A, Kirchberger MC, Toussaint F, Erdmann M, Schuler G, Heinzerling L. Effective anti-programmed death-1 therapy in a SUFUmutated patient with Gorlin-Goltz syndrome. Br J Dermatol. 2018; 179(3):747-749.

61. Lipson EJ, Lilo MT, Ogurtsova A, et al. Basal cell carcinoma: PD-L1/ PD-1 checkpoint expression and tumor regression after PD-1 blockade. J Immunother Cancer. 2017;5(1):23.

62. Falchook GS, Leidner R, Stankevich E, et al. Responses of metastatic basal cell and cutaneous squamous cell carcinomas to anti-PD1 monoclonal antibody REGN2810. J Immunother Cancer. 2016;4(1):70.

63. Goodman AM, Kato S, Cohen PR, et al. Genomic landscape of advanced basal cell carcinoma: Implications for precision treatment with targeted and immune therapies. Oncoimmunology. 2018;7(3):e1404217.

64. Lorusso PM, Rudin CM, Reddy JC, et al. Phase I trial of hedgehog pathway inhibitor vismodegib (GDC-0449) in patients with refractory, locally advanced or metastatic solid tumors. Clin Cancer Res. 2011; 17(8):2502-2511.

65. Graham RA, Lum BL, Cheeti S, et al. Pharmacokinetics of hedgehog pathway inhibitor vismodegib (GDC-0449) in patients with locally advanced or metastatic solid tumors: the role of alpha-1-acid glycoprotein binding. Clin Cancer Res. 2011;17(8):2512-2520.

66. Graham RA, Hop CE, Borin MT, et al. Single and multiple dose intravenous and oral pharmacokinetics of the hedgehog pathway inhibitor vismodegib in healthy female subjects. Br J Clin Pharmacol. 2012; 74(5):788-796.

67. Lorusso PM, Jimeno A, Dy G, et al. Pharmacokinetic dose-scheduling study of hedgehog pathway inhibitor vismodegib (GDC-0449) in patients with locally advanced or metastatic solid tumors. Clin Cancer Res. 2011;17(17):5774-5782.

68. Sharma MR, Karrison TG, Kell B, et al. Evaluation of food effect on pharmacokinetics of vismodegib in advanced solid tumor patients. Clin Cancer Res. 2013;19(11):3059-3067.
69. Sekulic A, Migden MR, Oro AE, et al. Efficacy and safety of vismodegib in advanced basal-cell carcinoma. $N$ Engl J Med Overseas Ed. 2012;366(23):2171-2179.

70. Sekulic A, Migden MR, Lewis K, et al. Pivotal ERIVANCE basal cell carcinoma (BCC) study: 12-month update of efficacy and safety of vismodegib in advanced BCC. J Am Acad Dermatol. 2015;72(6): 1021-1026.

71. Chang AL, Solomon JA, Hainsworth JD, et al. Expanded access study of patients with advanced basal cell carcinoma treated with the Hedgehog pathway inhibitor, vismodegib. J Am Acad Dermatol. 2014;70(1):60-69.

72. Basset-Seguin N, Hauschild A, Grob JJ, et al. Vismodegib in patients with advanced basal cell carcinoma (STEVIE): a pre-planned interim analysis of an international, open-label trial. Lancet Oncol. 2015; 16(6):729-736.

73. Orouji A, Goerdt S, Utikal J, Leverkus M. Multiple highly and moderately differentiated squamous cell carcinomas of the skin during vismodegib treatment of inoperable basal cell carcinoma. Br J Dermatol. 2014;171(2):431-433.

74. Mohan SV, Chang J, Li S, Henry AS, Wood DJ, Chang AL. Increased Risk of Cutaneous Squamous Cell Carcinoma After Vismodegib Therapy for Basal Cell Carcinoma. JAMA Dermatol. 2016;152(5): 527-532.

75. Bhutani T, Abrouk M, Sima CS, et al. Risk of cutaneous squamous cell carcinoma after treatment of basal cell carcinoma with vismodegib. J Am Acad Dermatol. 2017;77(4):713-718.

76. Tang JY, Ally MS, Chanana AM, et al. Inhibition of the hedgehog pathway in patients with basal-cell nevus syndrome: final results from the multicentre, randomised, double-blind, placebo-controlled, phase 2 trial. Lancet Oncol. 2016;17(12):1720-1731.

77. Lacouture ME, Dréno B, Ascierto PA, et al. Characterization and Management of Hedgehog Pathway Inhibitor-Related Adverse Events in Patients With Advanced Basal Cell Carcinoma. Oncologist. 2016; 21(10):1218-1229.

78. Dréno B, Kunstfeld R, Hauschild A, et al. Two intermittent vismodegib dosing regimens in patients with multiple basal-cell carcinomas (MIKIE): a randomised, regimen-controlled, double-blind, phase 2 trial. Lancet Oncol. 2017;18(3):404-412.

79. Chang AL, Atwood SX, Tartar DM, Oro AE. Surgical excision after neoadjuvant therapy with vismodegib for a locally advanced basal cell carcinoma and resistant basal carcinomas in Gorlin syndrome. JAMA Dermatol. 2013;149(5):639-641.

80. Mortier L, Bertrand N, Basset-Seguin N, et al. Vismodegib in neoadjuvant treatment of locally advanced basal cell carcinoma: First results of a multicenter, open-label, phase 2 trial (VISMONEO study). J Clin Oncol. 2018;36(15 Suppl):9509.

81. Shingler SL, Garside J, Samanta K, Lear JT, Keohane S, Lloyd AJ. Utilities for advanced basal cell carcinoma. J Med Econ. 2013;16(6): 777-783.

82. Axelson M, Liu K, Jiang X, et al. U.S. Food and Drug Administration approval: vismodegib for recurrent, locally advanced, or metastatic basal cell carcinoma. Clin Cancer Res. 2013;19(9):2289-2293.

83. Dreno B, Basset-Seguin N, Caro I, Yue H, Schadendorf D. Clinical benefit assessment of vismodegib therapy in patients with advanced basal cell carcinoma. Oncologist. 2014;19(8):790-796.

84. Chang AL, Lewis KD, Arron ST, et al. Safety and efficacy of vismodegib in patients aged $\geq 65$ years with advanced basal cell carcinoma. Oncotarget. 2016;7(46):76118-76124.

85. Danhof R, Lewis K, Brown M. Small Molecule Inhibitors of the Hedgehog Pathway in the Treatment of Basal Cell Carcinoma of the Skin. Am J Clin Dermatol. 2018;19(2):195-207.

86. Kaehler KC, Gutzmer R, Egberts F, Hauschild A. Regression of a basal cell carcinoma infiltrating the brain after vismodegib therapy. $J$ Dtsch Dermatol Ges. 2014;12(10):906-907.

87. Jameyfield E, Blondin N. Vismodegib treatment of intracranial invasion of basal cell carcinoma. Neurology. Apr 2017, 88(16 Supplement) P5.176. 
88. Cusack CA, Nijhawan R, Miller B, et al. Vismodegib for locally advanced basal cell carcinoma in a heart transplant patient. JAMA Dermatol. 2015;151(1):70-72.

89. Koelblinger P, Dummer R, Laimer M, et al. Vismodegib for recurrent locally destructive basal cell carcinoma in a renal transplant patient. J Eur Acad Dermatol Venereol. 2018;32(1):e7-e8.

90. Iarrobino A, Messina JL, Kudchadkar R, Sondak VK. Emergence of a squamous cell carcinoma phenotype following treatment of metastatic basal cell carcinoma with vismodegib. J Am Acad Dermatol. 2013;69(1):e33-e34.

91. Aasi S, Silkiss R, Tang JY, et al. New onset of keratoacanthomas after vismodegib treatment for locally advanced basal cell carcinomas: a report of 2 cases. JAMA Dermatol. 2013;149(2):242-243.

92. Zhu GA, Sundram U, Chang AL. Two different scenarios of squamous cell carcinoma within advanced Basal cell carcinomas: cases illustrating the importance of serial biopsy during vismodegib usage. JAMA Dermatol. 2014;150(9):970-973.

93. Giuffrida R, Kashofer K, Dika E, et al. Fast growing melanoma following treatment with vismodegib for locally advanced basal cell carcinomas: report of two cases. Eur J Cancer. 2018;91:177-179.

94. Ventarola DJ, Silverstein DI. Vismodegib-associated hepatotoxicity: a potential side effect detected in postmarketing surveillance. $\mathrm{J} \mathrm{Am}$ Acad Dermatol. 2014;71(2):397-398.

95. Ash MM, Jolly PS. Cholestatic hepatic injury associated with vismodegib, aspirin, and naproxen use: a case study and review of vismodegib safety. Int J Dermatol. 2015;54(3):370-374.

96. Vestita M, Lospalluti L, Giudice G, Bonamonte D, Rossiello I, Filoni A. Vismodegib and risk of cholestatic injury: should we screen candidate patients? Clin Exp Med. 2017;17(3):415-416.

97. BediPS, RaiMP, Tageja N,Laird-FickH. Hepatotoxicity Associated With Vismodegib. BMJ Case Rep. 2018;2018. pii: bcr-2017-222969.

98. Edwards BJ, Raisch DW, Saraykar SS, et al. Hepatotoxicity with Vismodegib: An MD Anderson Cancer Center and Research on Adverse Drug Events and Reports Project. Drugs R D. 2017;17(1):211-218.

99. Thomas CL, Arasaratnam M, Carlos G, et al. Drug reaction with eosinophilia and systemic symptoms in metastatic basal cell carcinoma treated with vismodegib. Australas J Dermatol. 2017;58(1):69-70.

100. Moreno-Arrones OM, Carrillo-Gijon R, Sendagorta E, Rios-Buceta L. Acute generalized exanthematous pustulosis simulating StevensJohnson syndrome/toxic epidermal necrolysis associated with the use of vismodegib. JAAD Case Rep. 2018;4(2):123-125.

101. Zhu GA, Li AS, Chang AL. Patient with Gorlin syndrome and metastatic basal cell carcinoma refractory to smoothened inhibitors. JAMA Dermatol. 2014;150(8):877-879.

102. Chang AL, Oro AE. Initial assessment of tumor regrowth after vismodegib in advanced Basal cell carcinoma. Arch Dermatol. 2012;148(11): 1324-1325.

103. Atwood SX, Sarin KY, Whitson RJ, et al. Smoothened variants explain the majority of drug resistance in basal cell carcinoma. Cancer Cell. 2015;27(3):342-353.

104. Brechbiel J, Miller-Moslin K, Adjei AA. Crosstalk between hedgehog and other signaling pathways as a basis for combination therapies in cancer. Cancer Treat Rev. 2014;40(6):750-759.

105. Kim AL, Back JH, Chaudhary SC, Zhu Y, Athar M, Bickers DR. SOX9 Transcriptionally Regulates mTOR-Induced Proliferation of Basal Cell Carcinomas. J Invest Dermatol. 2018;138(8):1716-1725.

106. Schnidar H, Eberl M, Klingler S, et al. Epidermal growth factor receptor signaling synergizes with Hedgehog/GLI in oncogenic transformation via activation of the MEK/ERK/JUN pathway. Cancer Res. 2009;69(4):1284-1292.

107. Zhao J, Quan H, Xie C, Lou L. NL-103, a novel dual-targeted inhibitor of histone deacetylases and hedgehog pathway, effectively overcomes vismodegib resistance conferred by Smo mutations. Pharmacol Res Perspect. 2014;2(3):e0043.
108. Gathings RM, Orscheln CS, Huang WW. Compassionate use of vismodegib and adjuvant radiotherapy in the treatment of multiple locally advanced and inoperable basal cell carcinomas and squamous cell carcinomas of the skin. J Am Acad Dermatol. 2014;70(4): e88-e89.

109. Pollom EL, Bui TT, Chang AL, Colevas AD, Hara WY. Concurrent Vismodegib and Radiotherapy for Recurrent, Advanced Basal Cell Carcinoma. JAMA Dermatol. 2015;151(9):998-1001.

110. Schulze B, Meissner M, Ghanaati S, Burck I, Rödel C, Balermpas P. Hedgehog pathway inhibitor in combination with radiation therapy for basal cell carcinomas of the head and neck: First clinical experience with vismodegib for locally advanced disease. Strahlenther Onkol. 2016;192(1):25-31.

111. Rizzo JM, Segal RJ, Zeitouni NC. Combination vismodegib and photodynamic therapy for multiple basal cell carcinomas. Photodiagnosis Photodyn Ther. 2018;21:58-62.

112. Shah M, Mavers M, Bree A, Fosko S, Lents NH. Quality of life and depression assessment in nevoid basal cell carcinoma syndrome. Int $J$ Dermatol. 2011;50(3):268-276.

113. Fife K, Herd R, Lalondrelle S, et al. Managing adverse events associated with vismodegib in the treatment of basal cell carcinoma. Future Oncol. 2017;13(2):175-184.

114. Girard E, Lacour A, Abi Rached H, et al. Occurrence of vismodegibinduced cramps (muscular spasms) in the treatment of basal cell carcinoma: A prospective study in 30 patients. $J$ Am Acad Dermatol. 2018;78(6):1213-1216.

115. Ally MS, Tang JY, Lindgren J, et al. Effect of Calcium Channel Blockade on Vismodegib-Induced Muscle Cramps. JAMA Dermatol. 2015;151(10):1132-1134.

116. Yuan JT, Tello TL, Hultman C, Barker CA, Arron ST, Yom SS. Medical marijuana for the treatment of vismodegib-related muscle spasm. JAAD Case Rep. 2017;3(5):438-440.

117. Kutiel TS, Vornicova O, Bar-Sela G. Cannabis for VismodegibRelated Muscle Cramps in a Patient With Advanced Basal Cell Carcinoma. J Pain Symptom Manage. 2018;55(5):e1-e2.

118. Cannon JGD, Tran DC, Li S, Chang AS. Levocarnitine for vismodegibassociated muscle spasms: a pilot randomized, double-blind, placebocontrolled, investigator-initiated trial. J Eur Acad Dermatol Venereol. 2018;32(7):e298-e299

119. Yang YW, Macdonald JB, Nelson SA, Sekulic A. Treatment of vismodegib-associated muscle cramps with cyclobenzaprine: A retrospective review. J Am Acad Dermatol. 2017;77(6):1170-1172.

120. Dessinioti C, Antoniou C, Stratigos AJ. From basal cell carcinoma morphogenesis to the alopecia induced by hedgehog inhibitors: connecting the dots. Br J Dermatol. 2017;177(6):1485-1494.

121. Alkeraye S, Maire C, Desmedt E, Templier C, Mortier L. Persistent alopecia induced by vismodegib. Br J Dermatol. 2015;172(6): 1671-1672.

122. Mcgarvey EL, Baum LD, Pinkerton RC, Rogers LM. Psychological sequelae and alopecia among women with cancer. Cancer Pract. 2001; 9(6):283-289.

123. Liu HX, Ermilov A, Grachtchouk M, et al. Multiple Shh signaling centers participate in fungiform papilla and taste bud formation and maintenance. Dev Biol. 2013;382(1):82-97.

124. Yang H, Cong WN, Yoon JS, Egan JM. Vismodegib, an antagonist of hedgehog signaling, directly alters taste molecular signaling in taste buds. Cancer Med. 2015;4(2):245-252.

125. Morinello E, Pignatello M, Villabruna L, Goelzer P, Bürgin H. Embryofetal development study of vismodegib, a hedgehog pathway inhibitor, in rats. Birth Defects Res B Dev Reprod Toxicol. 2014;101(2): 135-143. 


\section{Publish your work in this journal}

OncoTargets and Therapy is an international, peer-reviewed, open access journal focusing on the pathological basis of all cancers, potential targets for therapy and treatment protocols employed to improve the management of cancer patients. The journal also focuses on the impact of management programs and new therapeutic agents and protocols on

patient perspectives such as quality of life, adherence and satisfaction. The manuscript management system is completely online and includes a very quick and fair peer-review system, which is all easy to use. Visit http://www.dovepress.com/testimonials.php to read real quotes from published authors.

Submit your manuscript here: http://www.dovepress.com/oncotargets-and-therapy-journal 